ISSN : 2354 - 6034 (Print)

ISSN : 2599 - 0187 (Online)

\title{
PENGELOLAAN DAN ETIKA BISNIS ISLAM DI ISLAMIC RETAIL STORE 212 MART CABANG DUMAI
}

Mhd Erwin Munthe, Roviatul Fitriyah

Dosen Prodi Hukum Ekonomi Syariah Sekolah Tinggi Ilmu Ekonomi Syariah Bengkalis, Alumni jurusan Muamalat Institut Agama Islam Tafaqquh Fiddin Dumai Email: bmtherwinmunthe@gmail.com, roviatu11501548@gmail.com

Abstrak

In Indonesia, the Islamic retail store that first appeared in 2017 was the Islamic Retail Store 212 Mart, which was spearheaded by the Sharia cooperative 212. The retail is also the only market in the city of Dumai whose forms of business management and business ethics based on the Qur'an and As-Sunnah. Although legally positive, this does not include sharia cooperatives because there is no Sharia supervisory board (DPS) in the retail. One of the drivers of this retail existence is due to the awareness of the majority of Muslims to use and utilize products (goods and services) that are both legal and tayyib. This research included in the type of field or empirical research. While the approach is qualitative descriptive, this study aims to find out how the forms of management and business ethics applied at the Islamic Retail Store 212 Mart Dumai branch. The results of his research are the Islamic Retail Store 212 Dumai branch Mart in its management practices, and business ethics are following Islamic principles or values. Business management includes aspects of taqwa, balancelfairness, deliberation. In contrast, business ethics include Siddiq (honest and sincere), Amanah (responsibility, trustworthy, credibility), Tabligh (openness or transparency in the communication), Fathonah (smart, talented, wise).

\section{ABSTRAK}

Di Indonesia islamic retail store pertama kali muncul pada tahun 2017 adalah Islamic Retail Store 212 Mart yang dipelopori oleh koperasi Syariah 212. Retail tersebut juga merupakan satu-satunya market di kota Dumai yang bentuk pengelolaan bisnis dan etika bisnisnya berlandaskan al-qur'an dan As-Sunnah. Meskipun secara hukum positif bukan termasuk koperasi syariah karena belum adanya dewan pengawas syariah (DPS) pada retail tersebut. Salah satu pendorong adanya retail ini adalah karena adanya kesadaran masyarakat yang mayoritas muslim untuk menggunakan dan memanfaatkan produk-produk (barang maupun 


\section{Mhd Erwin Munthe, Roviatul Fitriyah}

jasa) yang halal dan tayyib. Penelitian ini termasuk pada jenis penelitian lapangan atau empiris. Sedangkan pendekatannya adalah bersifat kualitatif deskriptif. Penelitian ini bertujuan untuk mengetahui bagaimana bentuk pengelolaan dan etika bisnis yang diterapkan di Islamic Retail Store 212 Mart cabang Dumai. Hasil penelitiannya adalah Islamic Retail Store 212 Mart cabang Dumai dalam praktek pengelolaan dan etika bisnisnya sudah sesuai dengan prinsip atau nilai-nilai syariah. Pengelolaan bisnis tersebut meliputi aspek taqwa, keseimbangan/keadilan, musyawarah. Sedangkan etika bisnisnya meliputi Siddiq (jujur dan benar), Amanah (tanggung jawab, dapat dipercaya, memiliki kredibilitas), Tabligh (keterbukaan atau transparansi dalam berkomunikasi), Fathonah (cerdas, cerdik, bijaksana).

Keywords: Sharia business management, Sharia business ethics, Islamic Retail Store 212 Mart.

\section{PENDAHULUAN}

Islam muncul sebagai sumber kekuatan yang baru pada Abad ke 7 Masehi, menyusul runtuhnya kekaisaran Romawi. Kemunculan itu ditandai dengan berkembangnya beradaban baru yang sangat mengagumkan seperti kebudayaan, ilmu pengetahuan, teknologi dan kehidupan sosial lainnya termasuk ekonomi berkembang secara menakjubkan. ${ }^{1}$

Pada waktu yang lain Elie Kedourie mengatakan bahwa "it has become apparent that islam as a rule of life and system of thought is more popular than ever... (the new activism) shares the same vision of return to pure, pristine islam and the same desire that all aspects of life be ruled islamic norms". ${ }^{2}$

Pernyataan diatas dibuat lebih dari seperempat abad yang lalu. Pernyataan yang menggambarkan getaran semangat dunia Islam pada masanya dan masih berlanjut hingga kini. Kaum muslim terus-menerus menggelorakan persepsi bahwa Islam bukan hanya agama yang membimbing kehidupan individual dari aspek keimanan dan ibadah ritual, melainkan sebagai pandangan hidup sebagaimana ia juga merupakan sistem pemikiran dan filsafat. Dengan kata lain Islam meliputi petunjuk yang memadai untuk membangun tatanan masyarakat, kesatuan entitas politik, etika serta memberikan solusi bagi masalah-masalah manusia yang multidimensi. ${ }^{3}$

Kedua fakta sejarah diatas sesungguhnya memberikan notifikasi bahwa Islam merupakan agama atau sistem kehidupan yang bersifat komprehensif, yang mengatur semua aspek baik itu politik, sosial, bisnis maupun kehidupan yang bersifat spritual. Sebagaimana dijelaskan dalam firman-Nya dan kami turunkan kepadamu Al-Kitab (Al-Qur'an untuk menjelaskan sesuatu. "(Q.s An-Nahl:89).

Oleh karena itu Islam memandang bahwa bisnis sebagai salah satu aspek kehidupan, tentu juga sudah diatur oleh Islam. Ini bisa dipahami, sebagai agama yang sempurna, mustahil Islam tidak dilengkapi dengan sistem dan konsep bisnis.

\footnotetext{
${ }^{1}$ Mustafa Edwin Naustion, dkk, Pengenalan Eksklusif Ekonomi Islam, (Jakarta: Kencana, 2010), h.1.

${ }^{2}$ Juhaya S Pradja, Ekonomi Islam, (Bandung: Pustaka Setia, 2012), h.55.

${ }^{3}$ Juhaya S Pradja, Ekonomi Islam, h.55.
} 


\section{Mhd Erwin Munthe, Roviatul Fitriyah}

Suatu sistem yang dapat digunakan sebagai panduan bagi manusia dalam menjalankan kegiatan bisnis. Suatu sistem yang garis besarnya sudah diatur dalam Al-Qur'an dan As-Sunnah. ${ }^{4}$

Sistem diatas didefinisikan sebagai suatu organisasi berbagai unsur yang saling berhubungan satu sama lain. Unsur-unsur tersebut juga saling mempengaruhi dan saling bekerjasama untuk mencapai tujuan tertentu yaitu alfalah $^{5}$ kesejahteraan dunia dan akhirat, bahagia dan berhasil atau sebuah situasi yang didalamnya seorang individu dicukupi kebutuhan dasarnya dengan baik, serta menikmati kebebasan dan waktu luang yang diperlukan untuk meningkatkan mutu spritual dan moralnya. ${ }^{6}$ Peningkatan mutu spritual dalam ekonomi Islam menurut Jusmani akan berperan sebagai value judment yang menciptakan keseimbangan dalam pemenuhan kebutuhan tadi. Dalam literatur lain Umer Chapra ${ }^{7}$ mengatakan keimanan memegang peranan penting terhadap cara pandang, perilaku, gaya hidup,selera dan prefensi manusia dalam berekonomi.

Sistem ekonomi Islam dalam Al-qur'an dan As-Sunah, di berbagai ayat, dijelaskan bahwa terdapat beberapa prinsip bisnis Islam yang tidak boleh diabaikan oleh para pelaku bisnis, baik secara pribadi maupun sebagai kelompok bisnis, yaitu:

a. Tidak boleh menggunakan cara-cara yang bathil dan merusak. Pengaturannya dapat kita temukan dalam Q.S. Annisa ayat 29.

b. Tidak boleh melakukan kegiatan usaha dalam bentuk perjudian atau ada kemiripan dengan perjudian. Pengaturannya dapat kita temukan dalam QS. Al-Maidah ayat 90.

c. Tidak di dzalimi dan tidak mendzalimi. Pengaturannya dapat kita temukan dalam QS. Al-Baqarah ayat 279.

d. Tidak berlaku curang dalam takaran, timbangan ataupun pemalsuan kualitas. Pengaturan ini dapat kita lihat Q.S. Al-Mutaffifin ayat 1-6.

e. Tidak mempergunakan cara-cara yang ribawi atau dengan sistem bunga.

Pengaturan ini dapat kita lihat dalam QS.Al-Baqarah ayat 276.

Prinsip diatas merupakan bentuk pengaturan yang Allah tetapkan sebagai panduan agar bisnis yang dijalankan bernilai ibadah dan mendatangkan kemaslahatan baik bagi diri sendiri maupun untuk orang lain. Sehingga tujuan dari bisnis Islam itu sendiri yaitu Al-Falah dapat terealisasikan.

Indonesia merupakan salah satu negara yang perkembangan bisnis Islam nya kian marak dan menjamur. Salah satu pendorongnya adalah karena adanya kesadaran masyarakat yang mayoritas muslim untuk menggunakan dan memanfaatkan produk-produk (barang maupun jasa) yang halal dan tayyib. Maka peran produsen atau perusahaan-perusahaan bisnis berbasis syari'ah, menjadi sebuah alternatif yang cukup menjanjikan.

\footnotetext{
${ }^{4}$ Mustafa Edwin Naustion, dkk, Pengenalan Eksklusif Ekonomi Islam, h.2.

${ }^{5}$ Juhaya S Pradja, Ekonomi Islam, h.57.

${ }^{6}$ Muhammad Sharif Chaudry, Sistem Ekonomi Islam Prinsip Dasar, (Jakarta: Kencana Prenada Media Group, 2012), h.31.

${ }^{7}$ Mustafa Edwin Naustion, dkk, Pengenalan Eksklusif Ekonomi Islam, h.13.
} 


\section{Mhd Erwin Munthe, Roviatul Fitriyah}

Perkembangan itu di satu sisi patut disyukuri, namun pada sisi lain juga perlu diwaspadai.Karena bukan tidak mungkin, berbagai variasi produk syari'ah yang bermunculan saat ini ternyata tidak lebih dari sekedar 'berganti nama' saja. Artinya, secara paradigmatik sebuah perusahaan bisa saja tetap berpijak pada konsep bisnis sekuler-kapitalistik, tapi dipoles dengan label-label syari'ah atau tepatnya label etika Islami, seperti: jujur, amanah dan sejenisnya. Hasilnya, yang penting bagi perusahaan tersebut adalah mendapatkan market share yang menguntungkan di pasar syari'ah. Inilah tantangan bagi pengusaha muslim, dalam mengembangkan bisnis yang syariah. Bukan sekedar polesan, tapi juga asas, konsep, manusia, implementasi dan hasil yang benar-benar menampilkan karakter bisnis berbasis syari'ah yang utuh, unik dan barakah.

Prinsip-prinsip dalam Al-qur'an dan As-Sunnah diatas menjadi dasar utama dalam pengelolaan bisnis syari'ah yang dilakukan oleh pengusaha atau perusahaan. Sedangkan Etika Bisnis adalah seperangkat nilai tentang baik, buruk, benar dan salah dalam dunia bisnis berdasarkan pada prinsip-prinsip moralitas. Dalam arti lain etika bisnis berarti seperangkat prinsip dan norma dimana para pelaku bisnis harus komitmen dalam bertransaksi, berperilaku dan berelasi agar tujuan bisnisnya selamat. Selain itu etika bisnis juga dapat diartikan pemikiran tentang moralitas dalam ekonomi dan bisnis yaitu tentang perbuatan baik, buruk terpuji tercela, benar, salah, wajar, pantas, tidak pantas, dari perilaku seseorang berbisnis atau bekerja. Misalnya yang sering terjadi adalah dimana seorang pelaku usaha menaikkan harga secara berlipat-lipat dari harga pasar. Ini biasanya terjadi disebabkan adanya transaksi yang bersifat uncomplete information ${ }^{8}$, dimana pelaku usaha mengetahui harga barang dan jasa yang dijualnya, namun tidak memberitahukan kepada si pembeli sehingga pembeli tidak banyak mengetahui mengenai kualitas, kuantitas maupun harga barang tersebut.

Namun dengan berbagai model bisnis yang saat ini berkembang, tidak menutup kemungkinan prinsip dan etika tersebut banyak dilanggar sehingga berpotensi merugian pihak lain. Islam sangat melarang yang demikian itu terjadi. Dalam konteks itulah, maka model-model pengelolaan bisnis Islam menarik untuk diteliti.

Di Indonesia islamic retail store pertama kali muncul pada tahun 2017 yang dipelopori oleh koperasi Syariah 212. Koperasi syariah 212 ini berdiri di inisiasi oleh para tokoh-tokoh ulama dan umat muslim sebagai implementasi aksi damai pada tanggal 2 desember 2016 dalam kasus penistaan agama oleh salah satu gubernur di Indonesia yaitu Ahok. Semangat penuh kebersamaan dan persaudaraan menjadi latar belakang para tokoh-tokoh ulama dan umat muslim untuk memperjuangkan perekonomian yang mandiri maka dibentuklah sebuah wadah yang bernama gerai 212 Mart yang bernafaskan islami dibawah naungan Koperasi Syariah 212. Saat ini jaringan ritel 212 Mart sudah mencapai 100 gerai yang tersebar diberbagai kota di wilayah Indonesia dan salah satunya berdiri di kota Dumai Provinsi Riau.

Islamic Retail Store 212 Mart merupakan satu-satunya market khususnya di kota Dumai yang bergerak dalam bisnis retail syari'ah yang berlandaskan al-

${ }^{8}$ Jusmaliani, dkk. Bisnis Berbasis Syariah (Jakarta, Bumi Aksara 2008), h.101. 


\section{Mhd Erwin Munthe, Roviatul Fitriyah}

qur'an dan As-Sunnah. Islamic Retail Store 212 Mart merupakan unit usaha dibawah pengurusan koperasi amanah dumai berkah (Kop. ADAB).

Islamic Retail Store 212 Mart menjual barang kebutuhan sehari-hari seperti, bahan pokok, perlengkapan rumah tangga, alat tulis, dan lain-lain. Berbeda dengan minimarket pada umumnya, Islamic Retail Store 212 Mart tidak menjual rokok, minuman keras, alat kontrasepsi,dan produk yang tidak halal dalam menjalankan bisnisnya, karena istiqomahnya dalam menjalankan etika bisnis dan berdasarkan prinsip-prinsip syariah. Pernyataan tersebut, penulis dapatkan dari pernyatan masyarakat sekitar dan tinjauan langsung ke lokasi. Oleh karena itu peneliti tertarik untuk meneliti salah satu Islamic Retail Store 212 Mart yang berada di kota Dumai. Adapun permasalahan yang muncul dalam penelitian ini adalah: Bagaimana bentuk pengelolaan dan etika bisnis yang diterapkan di Islamic Retail Store 212 Mart cabang Dumai.

\section{METODE PENELITIAN}

Jenis penelitian ini termasuk pada jenis penelitian lapangan atau empiris. Sedangkan pendekatannya adalah bersifat kualitatif deskriptif ${ }^{9}$ yang digunakan untuk mendeskripsikan pengelolaan dan etika bisnis Islam pada Islamic Retail Store 212 Mart cabang Dumai. Penulis akan melakukan analisis dan interpretasi terhadap data, fakta, informasi tentang penerapan prinsip pengelolaan dana dan etika bisnis Islam di Islamic Retail Store 212 Mart cabang Dumai.

Dalam hal teknik pengumpulan data pertama kali penulis melakukan observasi awal ke lokasi penelitian yaitu Koperasi Amanah Dumai Berkah (Kop. ADAB) atau Gerai 212 yang berdiri di bawah koperasi syariah pusat, yang bergerak dalam Perdagangan ritel syariah dan merupakan satu-satunya Islamic Retail Store di kota Dumai tepatnya di Jl. Wan Dahlan Ibrahim (Merdeka) No. 85 Kota Dumai. Kemudian penulis melakukan wawancara dengan subjek-subjek penelitian mengenai bentul pengelolaan dana dan etika bisnis pada Islamic Retail Store 212 Mart langsung melakukan wawancara kepada Menejer, Ketua, Bendahara dan Sekretaris koperasi Dumai Berkah (Kop. ADAB) di gerai tersebut. Dokumentasi terkait dengan penelitian adalah barang-barang, tata letak, produk/merek barang yang dijual. Teknis analisa data dalam penelitian ini adalah diskriptif analisis yaitu menganalisis dan menyajikan fakta secara sistematis sehingga dapat lebih mudah di pahami dan di simpulkan. Setelah data di peroleh dan terkempul serta melalui proses pengolahan data, maka langkah selanjutnya adalah menganalisis data tersebut. Dalam kegiatan ini peneliti mengadakan pemeriksaan kembali terhadap semua data yang telah terkumpul kemudian dianalisis, untuk mendapatkan hasil penelitian yang jelas. Hasil penelitian ini akan dituangkan dibagian kesimpulan.

\section{PEMBAHASAN}

\section{Pengelolaan Bisnis Di Islamic Retail Store 212 Mart Cabang Dumai}

Pengelolaan atau manajemen berasal dari kata bahasa inggris yaitu“management" atau to manage yang artinya mengatur. Dalam bahasa Prancis

\footnotetext{
${ }^{9}$ Sugiyono, Metode Penelitian Kuantitatif Kualitatif dan $r \& d$ (Bandung: Alfabeta, 2011), h. 9
} 


\section{Mhd Erwin Munthe, Roviatul Fitriyah}

kuno kata pengelolaan atau manajemen berasal dari kata "menagement", yang berarti seni melaksanakan dan mengatur. Jadi manajemn itu merupakan suatu proses untuk mewujudkan tujuan yang diinginkan melalui aspek-aspeknya antara lain planning, organising, actuating, dan controling .

Sedangkan pengelolaan syariah adalah seni mengelola semua sumber daya yang di miliki dengan metode syariah yang telah tercantum dalm kitab suci atau yang telah di ajarkan oleh nabi Muhammad SAW. Pengelolaan syariah adalah suatu pengelolaan untuk mendapatkan hasil secara optimal dengan mengaharapkan ridho Allah. Dalam menjalankan pengelolaan tersebut harus berdasarkan aturanaturan Allah yang telah di jelaskaan dalam Al-Quran dan Hadist. ${ }^{10}$

Secara garis besar ada beberapa asas pengelolaan (manajemen) syariah menurut Al-qur'an yaitu:

\section{Taqwa}

Muhammad Al-Buzy ${ }^{11}$ dalam kitabnya Mafhum al-Taqwa fi al-Quran wa al-Hadits. Beliau mengatakan Takwa adalah rasa takut orang beriman kepada Tuhannya yang didasari oleh ilmu, senantiasa tetap dalam ketaatan kepadanya dengan melakukan (segala) kewajiban dan perbuatan-perbuatan yang dapat mendekatkan diri pada-Nya, serta menjauhi semua larangan, untuk mengharapkan pahala-Nya dan keselamatan dari balasan-Nya. Jadi pelaku bisnis yang bertaqwa adalah pelaku bisnis yang senantiasa bermuamalah dengan muamalah yang Islami atau berbisnis dengan tujuan untuk mendapatkan ridho Allah.

\section{Keseimbangan dan keadilan}

Islam mendefinisikan adil adalah "La tadzlimuna wa la tudzlamun" (Tidak mendzalimi dan tidak didzalimi). Impilkasi dari asas ini adalah pelaku bisnis tidak dibolehkan mengejar keuntungan pribadi bila hal itu merugikan orang lain atau merusak alam. ${ }^{12}$ Atau siapa saja berhak menjadi kaya karena hasil jerih payahnya sendiri, selama tidak melakukan kedzaliman. Dalam banyak ayat, Allah memerintahkan manusia untuk berbuat adil. Seperti pada Q.S. Al Hujurat ayat 9 dijelaskan bahwa "dan berlaku adillah. Sesungguhnya Allah menyukai orangorang yang berlaku adil". Dalam ayat lain Allah menjelaskan tentang balasan bagi orang yang tidak berlaku adil atau mendzalimi orang lain dalam hal mengurangi timbangan atau takaran ketika melakukan muamalah yaitu Q.S Al-Muthaffifin ayat 1-3 "celakalah bagi orang-orang yang curang, yaitu orang-orang yang apabila menerima takaran dari orang lain mereka minta dicukupkan, dan apabila mereka menakar atau menimbang (untuk orang lain) mereka mengurangi”.

\section{Musyawarah.}

Kata musyawarah dalam Islam (Al-qur'an) disebut dengan "syura"mencapai pendapat/buah fikiran. Abdul Hamid Al-Anshari dalam bukunya Nizam al-hukmi fi al-islam mengatakan bahwa syura (musyawarah)

\footnotetext{
${ }^{10}$ Sunarji Harahap, “Implementai Manajemen Syariah dalam Fungsi-Fungsi Manajemen”, Jurnal AtTawassuth Vol.2, No.1, (2017), h.212.

${ }^{11}$ Mat Saichon, “Makna Takwa Dan Urgensitasnya Dalam Al-Qur'an”, Ju r n a 1 U s r a h V o 1. 3, $\mathrm{No} .1$,

${ }^{12}$ Akhmad Mujahidin, Ekonomi Islam Sejarah, Konsep, Instrumen, Nrgara dan Pasar, Edisi Revisi, (Jakarta: Rajawali Pers, 2013), h. 26.
} 


\section{Mhd Erwin Munthe, Roviatul Fitriyah}

berarti saling merundingkan atau bertukar pendapat mengenai suatu masalah atau meminta pendapat dari berbagai pihak untuk kemudian dipertimbangkan dan diambil yang terbaik demi kemaslahatan bersama. ${ }^{13}$

Musyawarah juga tidak bisa di pisahkan oleh seorang leader yang hendak menuntaskan suatau perkara, agar keputusan yang di ambil bukan keputusan yang egois dari seorang diri saja, artinya keputusan itu dari hasil musyawarah. AlQur'an maupun As-sunnah menjelaskan tentang betapa pentingnya syura atau musyawarah dalam kehidupan berorganisasi maupun bermualah. Q.S. As-syu'ara ayat 38 "dan (bagi) orang-orang yang menerima (mematuhi) seruan Tuhannya dan mendirikan shalat, sedang urusan mereka (diputuskan) dengan musyawarat antara mereka". Pada masa nabi ketika Rasulullah memimpin kota Madinah musyawarah dijadikan sebagai prinsip kenegaraan dan aturan dalam sistem pemerintahan yang begitu intens dilakukan oleh Rasulullah sebagaimana tersurat dalam hadits "dari Abu Hurairah r.a dia berkata bahwa saya tidak pernah melihat seseorang yang paling sering melakukan musyawarah selain dari Rasulullah $S A W^{\prime \prime}$.

Dengan memahami system asas-asas diatas diharapkan dapat menjadi solusi terbaik bagi umat Islam, paling bisa mengambil sikap secara tepat dan bijak ketika harus bersinggungan dengan masalah-masalah kehidupan ekonomi global saat ini. $^{14}$

Selanjutnya berikut hasil wawancara yang telah peneliti lakukan mengenai prinsip pengelolaan bisnis syariah dengan pengelola/pengurus retail store 212 mart cabang Dumai.

Menurut bapak Syufri Buchari selaku ketua retail store 212 mart cabang Dumai beliau menceritakan bahwa pengelolaan retail store 212 mart modal awal pembangunan Koprasi Adab 212 berasal dari anggota sekitar 1,2 M yang digunakan untuk pembiayaan fisik dan bangunan. Sementara tanah tempat bangunan didirikan bukan milik koperasi. Sistemnya seperti senyewa-menyewa tapi uangnya untuk membangun koperasi. Kelemahan yang luar biasa karena, dengan persiapan waktu yang singkat, barang dari supplier yang memberikan kode dengan margin rata-rata $10 \%$, dan yang terjadi adalah barang ada yang terlalu mahal dan ada juga yang terlalu murah untuk mengejar target, berjalan selama hampir 1 bulan setelah itu harga stabil kembali.

Kemudian pak syufri buchari selaku ketua atau manager retail store 212 mart mengatakan secara hukum Koperasi Syariah 212 Mart Dumai bukan koperasi syariah", karena koperasi syariah itu mensyaratkan wajib punya dewan pengawas syariah (DPS) yang bersertifikat dan sampai sekarang belum ada DPS yang memiliki sertifikat. Jadi secara hukum 212 merupakan koperasi konvensional, Namun secara AD/ART Pengelolaan dan Etika bisnisnya sudah memacu ke syariah. Tetapi Islamic Retail Store 212 Mart Dumai tetap berkomitmen untuk menjadi koperasi syariah. Hanya saja untuk menjadikan koperasi syariah itu membutuhkan DPS dan harus mengikuti pelatihan selama setahun.

\footnotetext{
${ }^{13}$ Dudung Abdullah, “Musyawarah dalam Al-Qur'an (Suatu kajian tematik)”, Jurnal Al-Daulah, Vol.3, No.2, (2014), h. 245.

${ }^{14}$ M Ridwan.Konsep Pembangunan Menurut Ekonomi Islam dalam Buku Ekonomi dan Bank Syariah, (Medan: IAIN Press, 2002), h. 17.
} 
Dalam peraktik manajemen bisa dikatakan bahwasannya Islamic Retail Store 212 Mart Dumai, sudah menerapkan manajemen secara syariah, yang berasaskan Ketakwaan, Keseimbangan/keadilan dan Musyawarah. Hal ini dapat kita lihat dari:

1. Dalam praktek menjalankan bisnisnya, Islamic Retail Store 212 Mart Dumai sudah tersedia Mushola. Ketika masuk waktu sholat fardhu setiap karyawan di wajibkan untuk sholat fardhu. Bahkan setiap hari jum'at ketika waktu sholat jum'at Islamic Retail Store 212 Mart Dumai akan di tutup dan di buka kembali setelah selesai sholat Jum'at. Kebijakan seperti ini sudah sesuai dengan prinsip bahwa perdagangan tidak boleh melalikan diri dari ibadah yaitu (sholat, zakat dan sedekah). Al-Quran menjelaskan bahwa jangan sampai perniagaan itu melalaikan kita untuk mengingat Allah "Hai orang-orang beriman, apabila diseru untuk menunaikan shalat Jumat, Maka bersegeralah kamu kepada mengingat Allah dan tinggalkanlah jual beli yang demikian itu lebih baik bagimu jika kamu mengetahui." (QS Al-Jumu'ah: 9).

2. Islamic Retail Store 212 Mart Dumai dalam menjalankan bisnisnya dinyatakan sudah adil, yaitu tidak mendzalimi atau menempatkan sesuatu pada tempatnya. Dalam menjalankan bisnisnya Islamic Retail Store 212 Mart Dumai tidak Meresahkan masyarakat dan tidak merusak lingkungan. Dengan adanya Islamic Retail Store 212 Mart Dumai bisa membantu pertumbuhan Ekonomi masyarakat dengan menerima usaha rumahan masyarakat untuk di titipkan ke Gerai. Islamic Retail Store 212 Mart juga memiliki rasa sosial yang tinggi ini terlihat pada setiap hari jum'at Islamic Retail Store 212 Mart mengadakan Jum'at berkah yaitu kegiatan membagikan nasi gratis kepada masyarakat yang kurang mampu. Sebagaimana prinsip dalam ekonomi Islam setiap perdagangan harus di dasari sikap saling ridha di antara dua pihak, sehingga para pihak tidak merasa saling di rugikan atau di zalimi. "Seorang Muslim itu adalah saudara bagi Muslim yang lain, tidak boleh menzaliminya dan tidak boleh menelantarkannya" (HR. Muslim no. 2564).

3. Tidak adanya transaski riba

4. Tidak mendzalimi pembeli dengan mengurangi timbangan atau takaran

5. Islamic Retail Store 212 Mart dalam menjalankan bisnisnya selalu mengadakan musyawarah untuk menyelesaikan permaslahan dan mengambil keputusan. Islamic Retail Store 212 Mart sudah menjalankan fungsinya sebagai manajemen yaitu: planning, organising, actuating, dan controling.

6. Pembelian barang menggunakan sistem online

7. Penataan barang sudah dilakukan semenarik mungkin agar mengundang perhatian pembeli atau konsumen agar datang kembali. 


\section{Mhd Erwin Munthe, Roviatul Fitriyah}

8. Melakukan pencatatan yang baik dalam setiap transaksi.

9. Perdagangan terhindar produk-produk yang diharamkan, gharar, maupun maysir. Produk yang dijaul hanya produk yang bersifat harmfulness dan impuruty. Misalnya tidak menjual minuman khamar, rokok dan alat kontrasepsi.

\section{Etika bisnis dalam bertransaksi di Islamic Retail Store 212 Mart Dumai}

Menurut Solomon yang dikutip dalam Abdul Jalil etika menunjukkan dasar karakter individu untuk melakukan hal-hal yang baik, aturan sosial yang membatasi seseorang atas sesuatu yang benar atau yang salah yang dikenal juga dengan istilah moralitas. Etika adalah bagian dari filsafat yang membahas secara rasional dan kritis tentang nilai, norma atau moralitas. Terminologi yang paling dekat dengan pengertian etika dalam Islam disebut sebagai akhlak. ${ }^{1}$

Aristoteles mendefinisikan etika sebagai suatu kumpulan aturan yang harus dipatuhi oleh manusia. ${ }^{16}$ Etika juga memiliki stresing terhadap kajian sistem nilainilai yang ada. Di dalam era bisnis modern seperti pada saat ini, untuk menghadapi berbagai persaingan bisnis serta untuk mewujudkan persaingan yang sehat dalam bisnis, maka dikenal dengan istilah etika bisnis.

Etika bisnis digunakan sebagai pengendali perilaku persaingan bisnis agar sesuai dengan norma yang ada. Suatu persaingan bisnis dapat dinilai baik, apabila memenuhi seluruh norma yang ada. Etika bisnis juga dapat dipergunakan oleh para pelaku bisnis sebagai sumber paradigma dalam menjalankan suatu bisnis yang baik. ${ }^{17}$ Oleh karena itu apabila kita kaitkan etika dengan perdagangan dalam Islam, maka akan melahirkan suatu kesimpulan bahwa perdagangan atau bisnis harus mengacu nilai- nilai keislaman yang telah baku dari sumber aslinya yaitu al-Quran dan al- Sunnah. ${ }^{18}$

Aktivitas ekonomi dapat dibagi menjadi tiga beagian besar yaitu produksi, distribusi dan konsumsi. Apabila kita kaitkan dengan Islamic Retail Store 212 Mart Dumai, maka aktivitas tersebut masuk kepada aktivitas distribusi.

Permasalahan distribusi dalam aktivitas ekonomi seringkali terletak pada ketidakseimbangan distribusi kekayaan. Seringkali pelaku bisnis berkarakter sebagai homo economicus yang berdasarkan pada insting untuk menguasai segala hal dan untuk mengumpulkan harta sebanyak-banyaknya walaupun manusia menyadari bahwa waktu untuk hidupnya sangatlah terbatas. Sehingga karakteristik pelaku bisnis seperti ini akan membuatnya sebagai makhluk yang materialistik. ${ }^{19}$

Karakteristik pelaku bisnis materialistik akan membawa kepada pemikiran kepemilikan dimuka dunia ini dapat dikuasai oleh seorang atau segelintir orang saja. Karakteristik materialistik pun akan menghantarkan pada perbuatan-

\footnotetext{
${ }^{15}$ Fitri Amalia, "Etika Bisnis Islam: Konsep Dan Implementasi Pada Pelaku Usaha Kecil”, Jurnal AlIqtishad, Vol. 6, No. 1, (2014), h. 119-120.

${ }^{16}$ Aw . Wijaya, Etika Pemerintah, (Jakarta: Bumi Aksara, 1991), h.26

${ }^{17}$ Wahyu Mijil Sampurno, "Penerapan etika bisnis Islam dan dampaknya terhadap kemajuan bisnis industri rumah tangga", Journal of Islamic Economics Lariba (2016). vol. 2, issue 1: h. 13-18.

${ }^{18}$ Ahmad Charis Zubair, Kuliah Etika, (Jakarta: PT Raja Grapindo Persada, 1995), h. 13.

${ }^{19}$ Mustafa Edwin Naustion, dkk, Pengenalan Eksklusif Ekonomi Islam, 121.
} 
perbuatan yang merugikan banyak orang seperti ketidakjujuran, tidak amanah, menipu, mencuri, menaikkan harga dengan cara tidak wajar, menimbun dan lain sebagainya. Maka disinilah perlu adanya pengendali perilaku bisnis agar sesuai dengan norma yang ada.

Islam memberikan kebebasan kepada seseorang untuk melakukan bisnis, namun dalam Islam ada beberapa prinsip dasar yang harus dipatuhi atau menjadi etika normatif ketika seorang akan dan sedang menjalankan usaha, diantaranya:

\section{Siddiq (Jujur, benar)}

Sifat siddiq harus menjadi visi hidup setiap Muslim karena kita berasal dari yang maha benar, maka kehidupan didunia pun harus dijalani dengan benar, supaya kita dapat kembali kepada pencipta kita, yang maha benar. ${ }^{20}$ Orang yang siddiq berarti orang yang lurus yang memberikan suatu informasi apa adanya

tanpa menambahi atau mengurangi informasi tersebut apalagi sampai

memberikan informasi tidak sesuai dengan fakta yang ada. Dalam berbisnis, pelaku bisnis juga harus memiliki sifat jujur dan benar terhadap aktivitas yang ia lakukan. Rasulullah SAW sangat menganjurkan kejujuran dalam aktivitas bisnis, hal ini dapat kita temukan dalam suatu riwayat "Dari rifa'ah Ibnu Rafi r.a bahwa Nabi Saw pernah ditanya: pekerjaann apakah yang paling baik? Beliau bersabda: pekerjaan seseorang yang dengan tangannya dan setiap jual-beli yang dilakukan dengan cara mabrur (berkah)". (HR. Al Bazzar yang di shohihkan oleh Hakim).

Pengertian mabrur (berkah) pada hadist diatas dapat kita temukan dalam penjelasan hadits lain yang diriwayatkan oleh Imam Bukhari dan Imam Muslim yaitu "Jika penjual dan pembeli jujur dan menjelaskan apa adanya maka transaksi jual beli yang dilakukan itu akan diberkahi”. Jujur terkait keunggulan produk dan menjelaskan terkait kekurangan produk sehingga pedagang tidak mengatakan produk ini berkualitas bagus padahal jelek atau tahu ada cacat pada produknya.

\section{Amanah (Tanggung jawab, dapat dipercaya, memiliki kredibilitas)}

Prinsip amanah merupakan tanggung jawab atau bisa dipercaya. Sifat amanah memainkan peranan yang sangat fundamental dalam berbisnis. Amanah berarti memiliki tanggung jawab dalam melaksanakan setiap tugas dan kewajiban yang diemban. Amanah juga berarti pelaku bisnis dapat dipercaya oleh masyarakat terhadap tindakan, kata-katanya maupun pesan atau perintah yang dititipkan masyarakat kepadanya. Amanah juga berarti pelayanan yang optimal yang diberikan kepada orang. Tanpa tanggung jawab dan dapat dipercaya bisnis yang akan dijalankan akan mengalami kehancuran.

Allah mencintai orang yang giat bekerja dan bertanggung jawab "Sesungguhnya Allah SWT mencintai seorang mu'min yang giat bekerja" (HR. Thabrani). Dalam sebuah riwayat lain dikemukakan, "Pada suatu saat, Saad bin Muadz Al-Anshari berkisah bahwa ketika Nabi Muhammad SAW baru kembali dari Perang Tabuk, beliau melihat tangan Sa'ad yang melepuh, kulitnya gosong kehitam-hitaman karena diterpa sengatan matahari. Rasulullah bertanya,

\footnotetext{
${ }^{20}$ Akhmad Mujahidin, Ekonomi Islam Sejarah, Konsep, Instrumen, Nrgara dan Pasar, Edisi Revisi,
} h. 27. 
'Kenapa tanganmu?' Saad menjawab, 'Karena aku mengolah tanah dengan cangkul ini untuk mencari nafkah keluarga yang menjadi tanggunganku." Kemudian Rasulullah SAW mengambil tangan Saad dan menciumnya seraya berkata, 'Inilah tangan yang tidak akan pernah disentuh oleh api neraka”(HR. Tabrani)

Kedua riwayat diatas memberikan notifikasi bahwa Islam sangat menganjurkan dan menyukai pelaku bisnis yang bertanggung jawab terhadap tugas atau amanah yang diembankan kepadanya. Karena Islam mengajarkan setiap orang akan diadili pada hari kiamat nanti sesuai apa yang dia perbuat selama hidupnya.

\section{Tabligh (Keterbukaan atau transparansi dalam berkomunikasi)}

Tabligh merupakan komunikatif dan argumentatif. Pelaku bisnis yang memiliki sifat tabligh akan memiliki skill dalam menyampaikan informasi mengenai bisnis yang dia jalankan secara benar dan proporsional. Seperti pembuatan iklan atau pemasaran yang menarik dan jujur, lihai dalam berkomunikasi dengan konsumen, menyeru dan mengajak kepada hal-hal kebaikan dan memberitahu untuk meniggalkan kepada hal-hal yang dilarang.

Nabi misalnya mengajarkan bahwa "yang terbaik diantara kamu adalah yang paling bermanfaat bagi manusia”. Artinya bila ingin menyenangkan Allah, maka kita harus menyenangkan manusia. Pelaku bisnis yang baik adalah pelaku bisnis yang dapat menyenangkan masyarakat melalui komunikasi yang baik, tutur kata yang sopan dan penuh rasa ceria ketika melayani konsumen ataupun masyarakat.

\section{Fathonah (Cerdas, Cerdik, Bijaksana)}

Fathonah berarti memahami dan menghayati segala bentuk strategi yang dijalankan oleh pelaku bisnis. Pelaku bisnis yang fathonah mengerti akan kewajiban yang harus ia jalankan dan paham akan hak yang harusnya ia terima.

Sifat fathanah dalam penerapan kegiatan bisnis adalah segala sesuatu aktivitas dalam manajemen suatu perusahaan dengan kecerdasan. Pengoptimalan semua potensi yang dimiliki akal yang ada untuk mencapai tujuan. Jika seorang muslim hanya memilki sifat jujur, benar, dan tanggung jawab maka ketiga hal tersebut masih belum cukup dalam mengelola bisnis secara professional. Para pelaku bisnis syariah juga memiliki sebuah kecerdasan atau cerdas, cerdik dan bijaksana dengan tujuan agar usahanya bisa lebih efektif dan efisien serta mampu menganalisis situasi persaingan (complete setting) dan perubahan-perubahan (changes) di masa yang akan datang. Fathonah bagi pelaku bisnis yang bergerai dibidang retail seyogyanya memiliki strategi dan mampu mendistribusi produknya agar usaha yang dijalankan efektif dan efisien dan agar tidak menjadi korban penipuan dari konsumen maupun stakeholder lainnya.

Al-Qur'an menyindir tentang orang yang tidak mau belajar, yang tidak mau membaca dan yang tidak bisa dengan ungkapan yang sangat menarik, yaitu "adakah sama orang yang mengetahui dan orang yang tidak mengetahui".

Pada penelitian yang dilakukan di Islamic Retail Store 212 Mart cabang Dumai, dapat diambil beberapa hal terkait etika bisnis Islam yang diterapkan:

1. Dalam hal distribusi, Distributor sudah menjalankan sesuai dengan petunjuk syariah. Dengan menjauhi produk yang di larang oleh Allah dan Rasulnya yaitu tidak menjual produk-produk yang terlarang seperti 


\section{Mhd Erwin Munthe, Roviatul Fitriyah}

minuman keras dan produk-produk yang dimakruhkan yang dikhawatirkan lebih mendatangkan mudharat dibandingkan maslahat yaitu rokok dan alat kontrasepsi.

2. Startegi bisnis yang sesuai syariah dengan memberikan informasi harga yang benar sesuai dengan harga yang tercantum di rak produk.

3. Komunikasi para karyawan yang sopan, lembut dan berpakaian sesuai dengan petunjuk syariah.

4. Sikap tanggap dan cekatan dari karyawan ketika melayani pembeli atau konsumen

5. Harga yang kompetitif dan sesuai syariah meskipun diawal-awal harga cukup tinggi dibandingkan harga pasar

6. Tidak menerima produk titipan dari pelaku usaha rumahan kecuali jelas kehalalannya

7. Tidak melakukan investasi kepada saham yang dilarang oleh syariah

8. Tidak mengabaikan tujuan sosial dalam menjalankan bisnis. Hal ini terlihat pada setiap hari Jum'at adanya pembagian nasi kotak/bungkus kepada masyarakat yang kurang mampu.

Dengan etika bisnis yang dijalankan Islamic Retail Store 212 Mart cabang Dumai diatas kita dapat mengetahui bagaimana sesungguhnya bentuk pengelolaan dan etika bisnis yang dijalankan oleh retail-retail yang berbasis syariah. Kita juga dapat mengetahui bagaiamana perbedaan antara Islamic Retail Store dengan Conventional Retail Store.

\section{SIMPULAN}

Pengelolaan dan etika bisnis Islamic Retail Store 212 Mart cabang Dumai sudah sesuai dengan prinsip atau nilai-nilai syariah. Dalam peraktik manajemen bisa dikatakan bahwasannya Islamic Retail Store 212 Mart Dumai, sudah menerapkan manajemen secara syariah, yang berasaskan Ketakwaan, Keseimbangan/keadilan dan Musyawarah. Adapaun dalam etika bisnisnya pelaku bisnis Islamic Retail Store 212 Mart Dumai, sudah mematuhi etika normatif yang berdasarkan petunjuk Al-qur'an dan Hadist yaitu Siddiq (jujur dan benar), Amanah (tanggung jawab, dapat dipercaya, memiliki kredibilitas), Tabligh (keterbukaan atau transparansi dalam berkomunikasi), Fathonah (cerdas, cerdik, bijaksana).

\section{DAFTAR PUSTAKA}

\section{Buku}

Ahmad Charis Zubair, 1995. Kuliah Etika. Jakarta: PT Raja Grapindo Persada.

Akhmad Mujahidin, 2013. Ekonomi Islam Sejarah, Konsep, Instrumen, Nrgara dan Pasar, Edisi Revisi. Jakarta: Rajawali Pers.

Aw . Wijaya, 1991. Etika Pemerintah. Jakarta: Bumi Aksara.

Juhaya S Pradja, 2012. Ekonomi Islam. Bandung: Pustaka Setia. 
Jusmaliani, dkk. 2008. Bisnis Berbasis Syariah. Jakarta: Bumi Aksara.

M Ridwan, 2002. Konsep Pembangunan Menurut Ekonomi Islam dalam Buku Ekonomi dan Bank Syariah. Medan: IAIN Press.

Muhammad Sharif Chaudry, 2012. Sistem Ekonomi Islam Prinsip Dasar. Jakarta: Kencana Prenada Media Group.

Nasution, Mustafa Edwin, dkk. 2010. Pengenalan Eksklusif Ekonomi Islam. Jakarta: Kencana Prenada Media Group.

Sugiyono, 2011. Metode Penelitian Kuantitatif Kualitatif dan $r \& d$. Bandung: Alfabeta.

\section{Artikel/Karya Ilmiah}

Dudung Abdullah, "Musyawarah dalam Al-Qur'an (Suatu kajian tematik), Jurnal Al-Daulah, Vol.3, No.2, (2014), h. 245.

Fitri Amalia, "Etika Bisnis Islam: Konsep Dan Implementasi Pada Pelaku Usaha Kecil”, Jurnal Al-Iqtishad, Vol. 6, No. 1, (2014), h. 119-120.

Mat Saichon, “Makna Takwa Dan Urgensitasnya Dalam Al-Qur'an”, Jurnal Usrah Vol. 3, No. 1, (Juni, 2017), h. 44.

Sunarji Harahap, “Implementai Manajemen Syariah dalam Fungsi-Fungsi Manajemen”, Jurnal At-Tawassuth Vol.2, No.1, (2017), h.212.

Wahyu Mijil Sampurno, "Penerapan etika bisnis Islam dan dampaknya terhadap kemajuan bisnis industri rumah tangga", Journal of Islamic Economics Lariba (2016). vol. 2, issue 1: h. 13-18. 